\title{
HUBUNGAN KOMPETENSI PETANI DENGAN PENDAPATAN USAHATANI BAWANG MERAH (Allium ascalonicum L.) (Kasus di Desa Mulyasari Kecamatan Losari Kabupaten Cirebon)
}

\author{
THE CORRELATION FARMER'S COMPETENCE WITH \\ FARM INCOME OF SHALLOT (Allium ascalonicum. L) \\ (Case in Mulyasari Village, Losari District, Cirebon Regency)
}

\author{
Achmad Faqih \\ Program Studi Agribisnis Fakultas Pertanian Universitas Swadaya Gunung Jati \\ Jalan Pemuda No.32 Kota Cirebon \\ E-mail: afaqih024gmail.com
}

(Diterima 27-11-2021; Disetujui 22-01-2022)

\begin{abstract}
ABSTRAK
Keberhasilan petani dalam mengelola usahataninya khususnya tanaman bawang merah sangat ditentukan oleh kompetensi petani dalam melakukan usaha budidaya bawang merah, karena kompetensi merupakan suatu sifat dasar seseorang yang dengan sendirinya berkaitan dengan pelaksanaan suatu pekerjaan secara efektif dan efisien, serta perpaduan dari pengetahuan, keterampilan, nilai dan sikap yang direfleksikan dalam kebiasaan berfikir dan bertindak. Penelitian ini bertujuan untuk mengetahui: (1) hubungan kompetensi pengetahuan dengan pendapatan usahatani, (2) hubungan kompetensi sikap petani dengan pendapatan usahatani, dan (3) hubungan kompetensi keterampilan petani dengan pendapatan usahatani bawang. Penelitian dilakukan di Desa Mulyasari Kecamatan Losari Kabupaten Cirebon. Penelitian dilakukan dari bulan Oktober sampai Desember 2020. Desain penelitian yang digunakan dalam penelitian ini adalah penelitian kuantitatif, dengan teknik penelitian survey deskriptif. Pengumpulan data primer diperoleh melalui wawancara dengan petani responden menggunakan daftar pertanyaan, dan data sekunder diperoleh dari instansi yang ada kaitannya dengan penelitian ini. Untuk mengetahui hubungan kompetensi petani dengan pendapatan petani digunakan Uji korelasi jenjang Spearman. Hasil penelitian menunjukkan bahwa: (1) terdapat hubungan yang sedang dan nyata antara pengetahuan petani dengan pendapatan usahatani bawang merah, dengan nilai $r s=0,560$ dan nilai $t_{\text {hitung }}$ sebesar 5,060, (2) terdapat hubungan yang sedang dan nyata antara sikap petani dengan pendapatan usahatani bawang merah, dengan nilai rs $=0,544$ dan nilai $t_{\text {hitung }}$ sebesar 4,850, dan (3) terdapat hubungan yang sedang dan nyata antara keterampilan petani dengan pendapatan usahatani bawang merah, dengan nilai $r s=0,550$ dan nilai $t_{\text {hitung }}$ sebesar 4,927.
\end{abstract}

Kata Kunci : Kompetensi Petani dan Pendapatan Usahatani Bawang Merah

\section{ABSTRACT}

The success of farmers in managing their farming, especially shallot plants is largely determined by the competence of farmers in conducting onion cultivation, because competence is a basic trait of a person which is itself related to the implementation of a job effectively and efficiently, as well as a combination of knowledge, skills, values and abilities. an attitude that is reflected in the habit of thinking and acting. This study aims to determine: (1) the relationship between knowledge competence and farm income, (2) the relationship between the attitude competence of farmers and farm income, and (3) the relationship between farmer skills competence and onion farming income. The research was conducted in Mulyasari Village, Losari District, Cirebon Regency. The research was conducted from October to December 2020. The research design used in this study was a quantitative study, with a descriptive survey research technique. Primary data collection was obtained through interviews with respondent farmers using a list of questions, and secondary data obtained from agencies related to this research. To determine the relationship between farmer 


\section{HUBUNGAN KOMPETENSI PETANI DENGAN PENDAPATAN \\ USAHATANI BAWANG MERAH (Allium ascalonicum L.) \\ Achmad Faqih}

competence and farmer income, the Spearman level correlation test was used. The results showed that: (1) there was a moderate and significant relationship between farmer knowledge and onion farming income, with a value of $r s=0.560$ and a t-value of 5.060, (2) there was a moderate and significant relationship between farmer attitudes and onion farming income. red, with a value of $r \mathrm{~s}$ $=0.544$ and a tcount of 4.850, and (3) there is a moderate and significant relationship between farmer skills and onion farming income, with a value of $r s=0.550$ and a $t$-value of 4.927 .

Keywords: Farmer Competence and Shallot Farming Income

\section{PENDAHULUAN}

Tanaman bawang merah merupakan sayuran umbi yang multiguna, dapat digunakan sebagai bumbu masakan, sayuran, penyedap makanan, di samping sebagai obat tradisonal karena efek antiseptik senyawa anilin dan alisin yang dikandungnya (Rukmana, 2010). Bawang merah juga merupakan komoditas hortikultura yang tergolong sayuran rempah-rempah dan sumber penting karbohidrat, vitamin A, B dan C (Sun et al., 2019).

Salah satu penghasil bawang merah di Kabupaten Cirebon adalah Kecamatan Losari, khusunya Desa Mulyasari, bawang merah di daerah ini merupakan komoditi yang cukup penting dalam memberikan kontribusi terhadap peningkatan produksi sayuran dan memberikan pendapatan bagi petani (Dinas Pertanian dan Hortikultura Kabupaten Cirebon, 2019).

Produktivitas rata-rata bawang merah di Kabupaten Cirebon baru mencapai 7,82 ton per hektar (Dinas Pertanian dan Hortikultura Kabupaten
Cirebon, 2019). Produktivitas bawang merah tersebut masih rendah bila dibandingkan dengan potensial produktivitas bawang merah. Menurut Rahayu dan Berliana (2011), potensi hasil tanaman bawang merah dapat mencapai 12 ton per hektar.

Menurut Kastijadi (2009), salah satu penyebab rendahnya produktivitas suatu tanaman adalah para petani belum sepenuhnya menerapkan teknologi produksi. Sedangkan faktor yang mempengaruhi tingkat penggunaan teknologi tersebut adalah rendahnya tingkat kemampuan petani dalam memahami informasi serta memperoleh pengetahuan, rendahnya permodalan dan status pemilikan lahan, serta harga faktor produksi dan harga produksi. Produktivitas bawang merah yang rendah ini disebabkan oleh perubahan iklim dan pemanasan global yang telah mengakibatkan munculnya cuaca dan suhu ekstrim yang menyebabkan kekeringan dan banjir (Ghodke et al., 2018). 
Keberhasilan petani dalam mengelola usahataninya khususnya tanaman bawang merah sangat ditentukan oleh kompetensi petani dalam melakukan usaha budidaya bawang merah, karena kompetensi merupakan suatu sifat dasar seseorang yang dengan sendirinya berkaitan dengan pelaksanaan suatu pekerjaan secara efektif dan efisien, serta perpaduan dari pengetahuan, keterampilan, nilai dan sikap yang direfleksikan dalam kebiasaan berfikir dan bertindak. Mubyarto (2011) menyatakan bahwa petani adalah agen pembangunan yang berhubungan langsung dengan budidaya pertanian.

Kompetensi adalah kemampuan yang dimiliki oleh seorang petani bawang merah dalam melakukan usahatani budidaya bawang merah yang merupakan gabungan dari pengetahuan, sikap dan keterampilan yang diperlukan dalam pelaksanaan tugasnya, sehingga dapat melaksanakan tugasnya secara profesional, efektif dan efisien (Soekidjo, 2007). Dalam mengupayakan kualitas kerja petani, wajib memiliki kompetensi teknis dan manajerial, keduanya sangatlah penting karena kompetensi mengacu pada kemampuan seseorang untuk melakukan pekerjaan berdasarkan tingkat pengetahuan dan keterampilannya
(Bahua, 2018). Pengetahuan dan pelatihan merupakan kontributor keberhasilan perusahaan (Simpson dan Bellamy, 2004). Menurut Veerhes dan Meuleunberg (2004), kompetensi sangat penting untuk keberhasilan suatu usaha, beberapa kompetensi tersebut yaitu inovasi wirausaha, sikap positif terhadap pekerjaan, pengetahuan teknis dan pengalaman pelatihan sehingga akan menyebabkan keunggulan positif bahkan mengalami kenaikan pendapatan (Verhees dan Meulenberg, 2004).

Dari uraian di atas terlihat bahwa kompetensi petani sangatlah penting dalam rangka meningkatkan produksi dan pendapatan petani. Kompetensi petani dapat dianggap sebagai tumpuan dalam peningkatan produksi usahatani bawang merah yang dapat mendatangkan imbalan (pendapatan). Oleh karena itu, penulis tertarik untuk melakukan penelitian dengan judul: "Hubungan Kompetensi Petani dengan Pendapatan Usahatani Bawang Merah (Allium ascalonicum L.).

Tujuan penelitian ini adalah untuk mengetahui : (1) Hubungan kompetensi pengetahuan dengan pendapatan usahatani bawang merah (Allium ascalonicum L.), (2) Hubungan kompetensi sikap petani dengan pendapatan usahatani bawang merah 
(Allium ascalonicum L.), dan (3) Hubungan kompetensi keterampilan petani dengan pendapatan usahatani bawang merah (Allium ascalonicum L.).

\section{METODE PENELITIAN}

Penelitian dilakukan di Desa Mulyasari Kecamatan Losari Kabupaten Cirebon. Penelitian dilakukan dari bulan Oktober sampai Desember 2020.

Desain penelitian yang digunakan dalam penelitian ini adalah penelitian kuantitatif, dengan teknik penelitian survey deskriptif. Jumlah sampel penelitian sebanyak 48 petani bawang merah. Teknik penelitian menggunakan analisis korelasional untuk mengukur hubungan variabel/sub variabel terhadap variabel lain (Arikunto, 2012). Variabel penelitian terdiri atas kompetensi petani (X) yang meliputi: pengetahuan petani $\left(\mathrm{X}_{1}\right)$, sikap petani $\left(\mathrm{X}_{2}\right)$ dan keterampilan petani $\left(\mathrm{X}_{3}\right)$ dan variabel pendapatan usahatani bawang merah (Y).

Menurut Sugiyono (2012), untuk mengetahui hubungan variabel kompetensi petani sebagai variabel bebas dengan pendapatan usahatani bawang merah, sebagai variabel terikat/tidak bebas, digunakan Uji Koefisien korelasi jenjang Spearman (rs).

\section{HASIL DAN PEMBAHASAN}

\section{Karakteristik Responden}

Dari hasil wawancara diperoleh data mengenai karakteristik petani responden sebagai berikut:

a. Keadaan umur petani sebagian besar antara 35-45 tahun sebanyak 32 tahun $(66,67 \%)$, petani yang berumur antara 24-34 tahun sebanyak 10 orang $(20,83 \%)$, petani yang berumur antara 46-64 tahun sebanyak 6 orang $(12,50 \%)$.

b. Sebagian besar tamatan Sekolah Dasar 22 (45,83\%), tidak tamat SD sebanyak 7 orang $(14,58 \%)$, tamatan SMP sebanyak 10 orang (20,83\%), tamatan SMA sebanyak 7 orang $(14,58 \%)$, dan tamatan D3/S1 sebanyak 2 orang $(4,17 \%)$. Pendidikan petani responden tergolong dalam kategori rendah karena $45,83 \%$ berada pada kisaran 0 6 tahun atau setingkat hanya tamatan sekolah dasar. Rata-rata pendidikan petani adalah tamat $\mathrm{SD}$, hal ini menunjukkan jika sebagian besar petani kurang berpendidikan, petani adalah alternatif yang layak untuk tenaga kerja upahan bagi mereka yang tidak memiliki pekerjaan formal karena pendidikan yang terbatas (Ratta, 1993). Sebagian besar studi di 
Afrika, Asia dan Amerika Latin menunjukkan jika pendidikan memiliki pengaruh dan dampak positif pada produksi pertanian, namun nilai signifikansi dari penelitian ini seringnya lemah (Jamison, Dean dan Lau., 1982) .

c. Pengalaman petani dalam berusahatani di daerah penelitian sebagian besar berpengalaman antara 17-23 tahun sebanyak 21 orang $(43,75 \%)$ pengalaman petani peserta yang berpengalaman usahatani antara 10-16 tahun sebanyak 14 orang (29,17\%), berpengalaman antara 3-9 tahun sebanyak 9 orang $(18,75 \%)$, dan sisanya petani yang berpengalaman usahatani antara 2430 tahun sebanyak 4 orang $(8,33 \%)$. Menurut penelitian (Knowler, D., \& Bradshaw, 2007), pengalaman bertani sangat penting untuk mempermudah dan mempercepat adopsi teknologi pertanian. Hasil penelitian Ainembabazi et al. (2014) menyimpulkan bahwa pengalaman bertani berguna pada tahap awal adopsi teknologi teknologi tertentu.

d. Petani bawang merah, mempunyai luas lahan garapan kurang dari 0,25 ha yaitu sebanyak 9 orang $(18,75 \%)$, luas lahan antara 0,25-0,50 ha sebanyak 26 orang $(54,17 \%)$ dan mempunyai luas lahan lebih besar 0,75 ha sebanyak 13 orang $(27,08 \%)$.

e. Jumlah tanggungan keluarga responden sebagian besar memiliki tanggungan keluarga 3-4 orang, tergolong kategori sedang.

\section{Kompetensi Petani Bawang Merah}

Berdasarkan hasil wawancara dengan petani bawang merah, menunjukkan bahwa kompetensi petani bawang merah di Desa Mulyasari tergolong cukup baik, dengan skor ratarata kompetensi petani bawang merah sebesar 92,29 (72,10\%).

Pengetahuan petani bawang merah di Desa Mulyasari tergolong kategori cukup baik dengan skor rata-rata pengetahuan sebesar 57,81 (72,27\%). Sebagian besar petani bawang merah meyatakan bahwa pengetahuan petani tentang usahatani bawang merah tergolong cukup baik sebanyak 43 orang $(89,58 \%)$, dan sisanya tergolong kategori baik sebanyak 5 orang $(10,42 \%)$. Media dan metode berbeda yang digunakan oleh penyuluh untuk mengkomunikasikan hal dan teknologi baru kepada petani dapat meningkatkan produktivitas dan pengetahuan (Ekoja, 2003). Sedangkan penelitian (Nazari et al., 2011) menyimpulkan bahwa untuk menambah 
pengetahuan petani bisa melalui media massa seperti televisi karena menawarkan saluran dan menyebarkan informasi secara luas dan efisien.

Sikap petani dalam usahatani bawang merah di Desa Mulyasari tergolong kategori cukup baik dengan skor rata-rata sikap petani sebesar 16,96 (70,66\%). Sebagian besar anggota kelompok menyatakan bahwa sikap petani dalam kegiatan usahatani bawang merah tergolong cukup baik sebanyak 45 orang $(93,75 \%)$, dan kategori baik sebanyak 3 orang (6,25\%). Hasil penelitian Kabir (2015) menyimpulkan bahwa di Bangladesh sebesar 58,9\% sikap petani terhadap teknologi informasi dan komunikasi memiliki kategori cukup baik.

Keterampilan petani tentang usahatani bawang merah di Desa Mulyasari tergolong kategori cukup baik dengan skor rata-rata keterampilan petani sebesar 17,52 (73\%). Sebagian besar anggota kelompok menyatakan bahwa keterampilan petani dalam kegiatan usahatani bawang merah tergolong cukup baik sebanyak 36 orang ( $75 \%$ ), kategori baik sebanyak 11 orang $(22,92 \%)$, dan kategori kurang baik sebanyak 1 orang (2,08\%). Keterampilan petani didapat karena adanya penyuluhan teknis, pelatihan dan pengembangan petani pedesaan dengan cara memperkenalkan teknologi, memberikan metode dan memberikan keterampilan di bidang usaha tani (Baharein \& Noor, 2011), serta dengan mendemonstrasikan atau mempraktikkannya (Kraiger K., Ford, K., dan Salas, 1993).

\section{Pendapatan Usahatani Bawang}

\section{Merah}

Pendapatan petani bawang merah di Desa Mulyasari sebagian besar tergolong sedang (> Rp 10.855.000 - Rp 17.105.000), yaitu sebanyak 26 orang $(54,17 \%), \quad$ tergolong pendapatan usahatani tinggi ( $>$ Rp 17.105.000 - Rp $23.325 .000)$ sebanyak 10 orang (20,83\%) dan sisanya tergolong kategori rendah ( $\mathrm{Rp} 4.665 .000 \quad$ - $\mathrm{Rp}$ 10.855.000) sebanyak 12 orang (25\%).

\section{Hubungan Kompetensi Petani dengan Pendapatan Usahatani Bawang Merah}

\section{a. Hubungan Pengetahuan Petani dengan Pendapatan Usahatani bawang Merah}

Berdasarkan hasil perhitungan uji statistik Korelasi Rank Spearman, diperoleh nilai koefisien korelasi (rs) sebesar 0,560. Hal ini berarti hubungan antara pengetahuan petani dengan pendapatan usahatani bawang merah 
sebesar 0,560 , tergolong pada tingkat keeratan yang sedang. Nilai koefisien determinasi $\left(\mathrm{rs}^{2}\right)$ sebesar 0,314, artinya pengetahuan petani memberikan pengaruh terhadap pendapatan usahatani bawang merah sebesar 0,314 (31,40\%), dan sisanya sebesar $68,60 \%$ dipengaruhi oleh faktor lain yang tidak masuk dalam model. Dari hasil uji signifikansi (uji-t) diperoleh $t_{\text {hitung }}$ sebesar 5,060 lebih besar dari $\mathrm{t}_{0.05}$ sebesar 2,048 pada taraf nyata $5 \%$, artinya hubungan pengetahuan petani dengan pendapatan usahatani bawang merah berbeda nyata.

Pengetahuan (knowledge) adalah hasil tahu dari manusia terdiri atas sejumlah fakta dan teori yang memungkinkan seseorang untuk memecahkan masalah yang dihadapinya (Notoatmodjo, 2007). Pengetahuan pada hakekatnya merupakan segenap apa yang kita ketahui tentang suatu objek termasuk ke dalamnya adalah ilmu (Notoatmodjo, 2007). Lebih lanjut Notoatmodjo (2007), menyatakan bahwa terdapat dua cara yang pokok bagi manusia untuk mendapatkan pengetahuan yang benar. Cara pertama adalah mendasarkan diri pada rasio, dan yang kedua secara sederhana mendasarkan diri kepada pengalaman.
Menurut Sukmadinata (2003), terdapat beberapa faktor yang mempengaruhi pengetahuan seseorang. Faktor-faktor tersebut antara lain faktor internal dan faktor eksternal. Faktor internal terdiri atas jasmani dan rohani. Sedangkan faktor eksternal terdiri atas pendidikan, paparan media massa, status ekonomi, hubungan sosial dan pengalaman.

Menurut pendapat Bandura (2009), bahwa petani dapat belajar akibat dari tindakan mereka dan akan memperkaya serta mempertajam pengetahuannya. Pengamatan dan tanggapan seksama terhadap hasil uji coba atau observasi, bahkan kerugian akibat serangan hama dan penyakit serta kerusakan akibat alam (musim, iklim) akan lebih memperkaya sistem pengetahuannya. Pengetahuan petani juga dapat bertambah dari sumber eksternal seperti radio, televisi, tetangga dan penyuluh.

\section{b. Hubungan Sikap Petani dengan Pendapatan Usahatani bawang Merah}

Berdasarkan hasil perhitungan uji statistik Korelasi Rank Spearman, diperoleh nilai koefisien korelasi (rs) sebesar 0,544. Hal ini berarti hubungan antara sikap petani dengan pendapatan 
usahatani bawang merah sebesar 0,544 , tergolong pada tingkat keeratan yang sedang. Nilai koefisien determinasi $\left(\mathrm{rs}^{2}\right)$ sebesar 0,296, artinya sikap petani memberikan pengaruh terhadap pendapatan usahatani bawang merah sebesar 0,296 (29,60\%), dan sisanya sebesar 70,40\% dipengaruhi oleh faktor lain yang tidak masuk dalam model. Dari hasil uji signifikansi (uji-t) diperoleh $t_{\text {hitung }}$ sebesar 4,850 lebih besar dari $t_{0.05}$ sebesar 2,048 pada taraf nyata 5\%, artinya hubungan sikap petani dengan pendapatan usahatani bawang merah berbeda nyata.

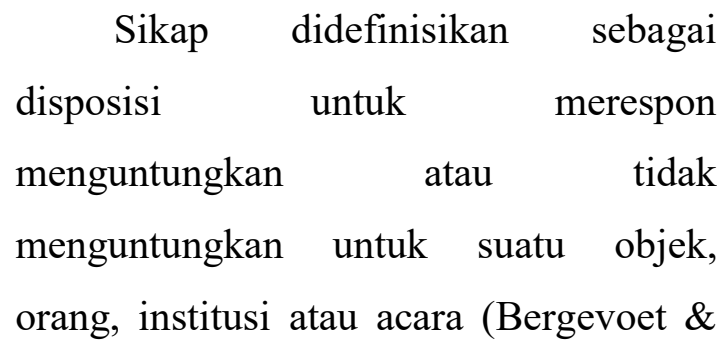
Huirne, 2004) (Bergevoet et. al., 2004). Menurut Azwar (2009), faktor-faktor yang mempengaruhi sikap salah satunya adalah pengalaman pribadi. Pengalaman pribadi meninggalkan kesan yang kuat sehingga sikap akan lebih mudah terbentuk apabila pribadi tersebut terjadi dalam situasi yang melibatkan faktor emosional. Berdasarkan hasil penelitian Sadati et. al (2010) menyimpulkan bahwa terdapat hubungan positif antara literasi, partisipasi dalam program penyuluhan, sikap petani, pengetahuan petani dengan pendapatan dan kepuasan kerja.

Menurut Calhoun (2000), bahwa sikap memiliki tiga sumber utama, yaitu pengalaman pribadi, sikap dapat merupakan hasil pengalaman yang menyenangkan atau menyakitkan dengan objek sikap. Kemungkinan kedua sumber sikap dalam hal ini sikap negatif adalah pemindahan perasaan yang menyakitkan. Sumber ketiga dari sikap adalah pengaruh sosial dan kemungkinan akan menjadi sumber uatama. Sedangkan Edward (2001) mengemukakan sikap adalah derajat atau tingkat kesesuaian seseorang terhadap objek tertentu. Sekalipun diasumsikan bahwa sikap merupakan predisposisi evaluatif yang banyak menentukan bagaimana individu bertindak, akan tetapi sikap dan tindakan nyata seringkali jauh berbeda. Hal ini dikarenakan tindakan nyata tidak hanya ditentukan oleh sikap semata, akan tetapi oleh berbagai faktor eksternal lainnya. Di samping itu, ternyata untuk satu macam tindakan saja terdapat banyak pola sikap yang relevan. Karena itu ketidak harmonisan sikap lebih merupakan masalah orientasi indivisu terhadap situasi yang ada. Pada dasarnya sikap memang lebih bersifat pribadi sedangkan tindakan atau kelakuan lebih bersifat 
umum atau sosial (Mann, 1999). Sehingga perubahan dari sikap ini sering bersifat situasional. Sedangkan kegunaan dari perubahan sikap dapat dipakai untuk pendidikan dan aplikasi sehari-hari.

\section{c. Hubungan Keterampilan Petani dengan Pendapatan Usahatani bawang Merah}

Berdasarkan hasil perhitungan uji statistik Korelasi Rank Spearman, diperoleh nilai koefisien korelasi (rs) sebesar 0,550. Hal ini berarti hubungan antara keterampilan petani dengan pendapatan usahatani bawang merah sebesar 0,550 , tergolong pada tingkat keeratan yang sedang. Nilai koefisien determinasi $\left(\mathrm{rs}^{2}\right)$ sebesar 0,302, artinya keterampilan petani memberikan pengaruh terhadap pendapatan usahatani bawang merah sebesar 0,302 (30,20\%), dan sisanya sebesar $69,80 \%$ dipengaruhi oleh faktor lain yang tidak masuk dalam model. Dari hasil uji signifikansi (uji-t) diperoleh $t_{\text {hitung }}$ sebesar 4,927 lebih besar dari $\mathrm{t}_{0.05}$ sebesar 2,048 pada taraf nyata $5 \%$, artinya hubungan keterampilan petani dengan pendapatan usahatani bawang merah berbeda nyata.

Keterampilan petani dapat berhasil jika ditunjang oleh pengetahuan berusahatani jagung yang dapat berimplikasi pada peningkatan produksi bawang merah. Hasil penelitian ini sejalan dengan penelitian dari Sudirman (2006) yang menyimpulkan bahwa model pelatihan keterampilan petani diarahkan pada pengembangan usaha produktif yang disesuaikan dengan kondisi lingkungan, serta dilakukan secara terpadu. Hasil penelitian dari Bandolan, dkk (2008) menyimpulkan bahwa tingginya keterampilan petani disebabkan oleh adanya pengetahuan yang dimiliki oleh petani sehingga keterampilan mencakup pemilihan bibit unggul, penanaman, pemeliharaan dan panen dapat dilakukan. Ketrampilan menunjukkan suatu proses peningkatan sikap, kemampuan, dan kecakapan dari para pekerja untuk menyelenggarakan pekerjaan secara khusus". Ungkapan ini menunjukkan kalau kegiatan pelatihan merupakan proses membantu peserta belajar untuk memperoleh keefektifan dalam melakukan pekerjaan mereka baik pada saat sekarang maupun masa yang akan datang melalui pengembangan kebiasaan pikiran dan tindakan-tindakan, kecakapan, pengetahuan, dan sikap-sikap dalam bekerja. Hasil penelitian Jolliffe (1998) menyimpulkan bahwa keterampilan memiliki efek positif pada pendapatan total dan signifikan secara statistik terhadap pendapatan usahatani. 


\section{KESIMPULAN DAN SARAN}

\section{Kesimpulan}

Berdasarkan hasil penelitian dan pembahasan yang telah diuraikan dimuka, maka dapat ditarik kesimpulan sebagai berikut:

1) Terdapat hubungan yang sedang dan nyata antara pengetahuan petani dengan pendapatan usahatani bawang merah, dengan nilai $\mathrm{rs}=0,560$ dan nilai $t_{\text {hitung }}$ sebesar 5,060.

2) Terdapat hubungan yang sedang dan nyata antara sikap petani dengan pendapatan usahatani bawang merah, dengan nilai $r s=0,544$ dan nilai $t_{\text {hitung }}$ sebesar 4,850 .

3) Terdapat hubungan yang sedang dan nyata antara keterampilan petani dengan pendapatan usahatani bawang merah, dengan nilai rs $=0,550$ dan nilai $t_{\text {hitung }}$ sebesar 4,927 .

\section{Saran}

Dari berbagai kesimpulan di atas, maka dapat dikemukakan saran-saran sebagai berikut :

1) Perlu terus ditingkatkan pengetahuan dan keterampilan petani melalui pembinaan dan penyuluhan, sehingga anggota kelompok termotivasi untuk meningkatkan pengetahuan usahatani bawang merah dalam rangka meningkatkan pendapatan petani.

2) Perlu terus ditingkatkan pengetahuan dan keterampilan petani melalui pendidikan non formal, seperti pelatihan teknis dan pengelolaan keuangan kelompok, dalam rangka pengembangan usahatani bawang merah dalam rangka meningkatkan pendapatan petani.

\section{DAFTAR PUSTAKA}

Ainembabazi, J. H., Mugisha, J., Ainembabazi, J. H., \& Mugisha, J. (2014). The Role of Farming Experience on the Adoption of Agricultural Technologies : Evidence from Smallholder Farmers in Uganda The Role of Farming Experience on the Adoption of Agricultural Technologies: Evidence from Smallholder Farmers in Uganda, 50(2), 666-679

Azwar, S. (2009). Sikap Manusia. Teori dan Pengukurannya. Pustaka Pelajar, Yogyakarta

Baharein, K., \& Noor, M. (2011). Investigating Training Impact on $\mathrm{F}$ armers Perception and Performance. International Journal of Humanities and Social Science, $1(6), 145-152$.

Bahua, M. I. (2018). Factors that Deals between Competence Agricultural Extension Workers and Skill Farmers Shallot. 3(10), 493-498.

Bandura, A. (2009). Sosial Learning Theory. Englewood Clifts Inc. New Jersey Prentice-Hall

Bandolan Y., Abd. Azis, dan Sumang. (2008). Tingkat Adopsi Petani 
terhadap Teknologi Budidaya Rambutan di Desa Romangloe Kecamatan Bontomarannu Kabupaten Gowa. Jurnal Agrisistem. Vol. 4 No. 2. Desember 2008. Hal: $5-12$

Bergevoet. (2004). Entrepreneurial Behavior of Dutch Dairy Farmers Under a Milk Quota System: Goals, Objectives and Attitudes. Agr. Sys, 80, 1-20.

Calhoun, C. (2000). The Virtue of Civility. Philosophy and Public Affairs, 29(3), 251-275.

Dinas Pertanian dan Hortikultura Kabupaten Cirebon. (2019). Perkembangan Teknologi Pertanian Tanaman Padi, Palawija dan Sayuran. Dinas Pertanuan Perkebunan Peternakan dan Kehutanan Kabupaten Cirebon, Cirebon.

Edward, J. R. (2001). Multidimensional Construct in Organizational Behavior Research: A Integrative Analytical Framework. Organizational Research Methods, 2(5), 175-187.

Ekoja, I. (2003). Farmer's Access to Agricultural Information in Nigeria. Bull. Am. Soc. Info. Sci. Technol, 29(6), 21-33.

Estu Rahayu dan Nur Berliana. (2011). Bawang Merah. Penebar Swadaya, Jakarta

Ghodke, P. H., Andhale, P. S., Gijare, U. M., \& Thangasamy, A. (2018). Physiological and Biochemical Responses in Onion Crop to Drought Stress. 7(01), 2054-2062.

Indrianingsih. (2011). Pengaruh Penyuluhan terhadap Keputusan Petani dalam Adopsi Inovasi Teknologi Usahatani Terpadu. Jurnal Agro Ekonomi. Volume 29 No. 1, Mei 2011.

Jamison, Dean T., and L. J. L. (1982). Farmer Education and Farm
Efficiency. World Bank.

Jolliffe, D. (1998). Skills , Schooling, and Household Income in Ghana. The World Bank Economic Review. 12(1) 81-104

Kabir, K. H. (2015). Attitude and Level of Knowledge of Farmers on ICT based Farming General Background changing world has been recognized as an essential mechanism the door step of the farmers . productive and profitable than they could be. The reasons at the right time and place (De Silva and Ratnadiwakara , accessing required information and knowledge) Richardson. II(10), 13177-13196.

Kastijadi, F. (2009). Faktor-Faktor Yang Mempengaruhi Terhadap Peningkatan Produksi Bawang Merah Di Jawa Timur. Laporan Hasil Penelitian. Balai Penelitian Holtikultura, Malang.

Knowler, D., \& Bradshaw, B. (2007). Farmer's Adoption of Conservation Agriculture: A Review and Synthesis of Recent Research. Food Policy, 32, 25-48.

Kraiger K., Ford, K., \& Salas, E. (1993). Application of Cognitive, SkillBased, and Affective Theories of Learning Outcomes to New Methods of Training Evaluation. Journal of Applied Psychology, 78(2), 311-328.

Mann, J. (1999). Behavioral Sampling Methods For Cetaceans: A Review and Critique. Marine Mammal Science, 15(1), 102-122.

Mohamad Ikbal Bahua. (2013). Hubungan Karakteristik Petani Dengan Kompetensi Usahatani Jagung di Tiga Kecamatan di Kabupaten Pohuwato. Studi Ilmu dan Teknologi Pangan Universitas Goreontalo. 
Mubyarto. (2011). Pengantar Ekonomi Pertanian. Lembaga Penelitian, Pendidikan dan Penerangan Ekonomi dan Sosial, Jakarta

Nazari, M. R., Bin, S., \& Hassan, H. (2011). The role of television in the enhancement of farmers agricultural knowledge. 6(4), 931936.

Notoatmodjo Soekidjo. (2007). Ilmu Perilaku dan Sikap. Rineka Cipta, Jakarta

Ratta, A. (1993). City Women Farm for Food and Cash. Intl. Ag-Sieve, $6(2), 1-2$.

Rukmana. (2010). Bawang Merah. Budidaya dan Pengelolaan Pascapanen. Kanisius, Yogyakarta

Sadati, A Hossein Shabbanali Fami, Ali Asadi, S. A. S. (2010). Farmer's Attitude on Sustainable Agriculture and Its Determinants: A Case Study in Behbahan Country of Iran. Research Journal of Applied Sciences, Engineering and Technology, 2(5).

Simpson, M., N. T. and S. Bellamy. (2004). Small Business Success Factors: The Role of Education and Training. Education and Training, 46(89), 481-491.
Sudirman. (2007). Model Pelatihan Keterampilan Usaha Terpadu bagi Petani sebagai Upaya Alih Komoditas. Laporan Hasil Penelitian. http://damandiri.or.id. Diakses 21 Oktober 2020.

Sugiyono. (2012). Statistika Untuk Penelitian. Alfabeta, Bandung.

Suharsimi Arikunto. (2012). Prosedur Penelitian Suatu Pendekatan Praktik. Rineka Cipta, Jakarta.

Sukmadinata, T. (2003). Sistem Pengelolaan terminal Agribisnis dan Sub terminal Agribisnis Secara Terpadu untuk Memberikan Nilai Tambah Pelaku dan Produk Agribisnis. Makalah pada Apresiasi manajemen kelayanan Terminal Agribisnis, Sub Terminal Agribisnis

Sun, W., Shahrajabian, M. H., \& Cheng, Q. (2019). The insight and survey on medicinal properties and nutritive components of Shallot. 13(18), 452-457.

Verhees, F. J. H. M. and M. T. G. M. (2004). Market Orientation, Innovativeness, Product Innovation, and Performance in Small Firms. Journal of Small Business Management, 42(2), 134-154. 